〈技術報告〉

\title{
北海道における早刈り，短間隔刈りで収穫したオーチャードグラス・ ペレニアルライグラス混播草地由来牧草サイレージの飼料特性
}

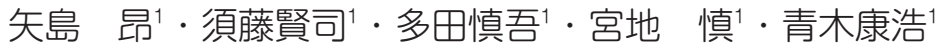 \\ 1 農研機構北海道農業研究センター, 札幌市 062-8555
}

(2019. 10. 9 受付, 2020. 3. 19 受理)

\begin{abstract}
要 約 北海道におけるオーチャードグラス $(O G)$ とペレ二アルライグラス（PR）の混播採草地から早 刈り, 短間隔杊り体系によって生産されるサイレージ材料草の WSC 含量と, サイレージの飼料成分, 発酵 品質, 栄養価について, 北海道で慣行的に行われているチモシー (TY) 1 番草出穂期刚りによる年間 2 回刚 り体系を対照として検討した. OG・PRは 1 番草を OG の出穂始めに, 2 番草および 3 番草をその後約 6 週間間隔で収穫・調製した。 また, TYは 1 番草を出穂期に, 2 番草をその約 9 週間後に収穫・調製した。 $O G \cdot P R$ は, 特に 1 番草でサイレージ材料草の WSC 含量が高<, 調製されたサイレ一ジの発酵品質が良好 であった．また，OG・PRサイレージは CP およびTDN 含量が高く纎維含量が低かった，以上より，OG. PRの早刈り, 短間隔刈り利用にはサイレージの発酵品質や栄養価の向上といつた利点があることが明らかに なった.
\end{abstract}

日本畜産学会報 91 (3), 275-280, 2020

キーワード : 栄養価, オーチャードグラス, 発酵品質, ペレ二アルライグラス, 牧草サイレージ

北海道では，耐寒性に優れ，安定した生産力を示すチモ シー (Phleum pratense L., TY)（小林 2014a）が基幹 草種として採草利用されている. 栄養収量や作業性の観点 から, TY草地については, 出穂期から開花前頃に 1 番草 を収穫し，年間 2 回刈りでの利用が一般的である。一方, TYは再生力が劣り他草種との競合に弱いため（藤井 2010),TY主体採草地において地下茎型イネ科雑草の侵 入による草種構成の悪化や収量の低下, さらに収穫調製さ れた牧草サイレージの栄養価や発酵品質の低下が問題亡 なっている（出 $\square 2016$; 北村 2016）。特に, 高栄養牧草 の生産を目指したTY採草地の早刚り体系では, 草種構成 の悪化を招く可能性が指摘されている（木曾と能代 1994, 1997)，このため, 競合力や再生力に優れ，栽培管理によ る栄養価向上が可能な草種によるサイレージ材料草の生産 が望まれている.

近年, 北海道内では再生力が優れるため雑草との競合に 強いオーチャードグラス (Dactylis glomerata L., OG) （小林 2014b）亡, 可溶性炭水化物（WSC）含量が高< 繊維含量が少ないため栄養価が高いペレニアルライグラス (Lolium perenne L., PR)（増子ら 1994a, b) との混播 草地を採草利用する技術に関心が高まっている。道北地域 において, OGとPRの混播草地はリードカナリーグラス 等雑草の侵入がTY草地に比べ少ないこと，年 3 回刈りの 混播草地の乾物収量は各草種の単播草地よりも高いことが
報告されている（上川農試天北支場 2016）。一般に，イ ネ科牧草は生育ステージが進むとともに乾物（DM）収量 は増加する一方で, 粗タンパク質 $(\mathrm{CP})$ 含量の減少や繊 維含量の増加といつた成分変化や，消化率の低下が生じる (McDonald 51991 ; 増子5 1994a)。OG 主体草地に ついては, 1 番草を TY 主体草地の収穫時期よりも 1 2 週間程度早期に収穫し, その後約 6 週間程度の間隔で収 穫することで，栄養価の高い飼料が調製できると期待され る (谷津 2017). しかしながら, 道内における OG・PR 草地から生産されるサイレージの飼料成分, 栄養価および 発酵品質についての知見は少ない，そこで，本研究では北 海道で慣行的に行われている年間 2 回刈りで収穫した TY 主体牧草サイレージを対照として, 早刈り, 短間隔刈りで 収穫した OG.PR 混播牧草サイレージの飼料特性を明ら かにすることを目的として，北海道札幌市における OG PR 混播およびTY草地を供試して, サイレージ材料草の WSC 含量と, サイレージの飼料成分組成，発酵品質，栄 養価について調査を行った。

\section{材料および方法}

\section{1. 供試戋場および牧草サイレージの調製方法}

本研究は, 農研機構北海道農業研究セン夕一 (札幌市) において 2018 年に実施した. 今回供試したサイレージの 材料草は, $O G \cdot P R, T Y$ ともに造成後 3 年目の採草地か

連絡者: 矢島 昂 (fax: 011-859-2178, e-mail : yajimaa156@affrc.go.jp)

日畜会報 91 (3)：275-280, 2020 
ら収穫し，品種は「八ルジマン」(OG) および「チニ夕」 (PR) と「キリタップ」(TY) とした. 各草地の施肥管理 と, 材料草の刚り取り日および収穫日は宮地ら (2020)の 通りであり，その概要を表 1 および表 2 に示した，OG・ $\mathrm{PR}$ は 1 番草を $O G$ の出穂始めに, 2 番草および 3 番草を その後約 6 週間間隔で収穫・調製した．また，TYは 1 番 草を出穂期に, 2 番草をその約 9 週間後に収穫·調製した. 各材料草の草種構成および収量は宮地ら（2020）の通り であり，その概要を図 1 および表 3 に示した.

刈り取り後の材料草は予乾後, 細断型口ールベールサイ レージ (設定切断長 : $6 \mathrm{~mm}$, 添加剤：無し) として調製し

表 1 オーチャードグラス・ペレニアルライグラス混播 草地早刈り，短間隔刈り体系およびチモシ一主体草地年間 2 回刈り体系における施肥管理（宮地ら 2020，施肥量： $\left.\mathrm{N}-\mathrm{P}_{2} \mathrm{O}_{5}-\mathrm{K}_{2} \mathrm{O} / 10 \mathrm{a}\right)$

\begin{tabular}{lcc}
\hline \hline \multicolumn{1}{c}{ 施肥時期 } & $O G \cdot P R$ & $T Y$ \\
\hline 早春 & $6.0-6.0-6.4$ & $6.0-6.0-6.4$ \\
1 番草刚り取り後 & $8.3-0-0$ & $6.0-0-0$ \\
2 番草刚り取り後 & $4.5-0-0$ & なし
\end{tabular}

OG:オーチャードグラス, PR:ペレ二アルライグラス, TY : チモシー
た. 材料草は予乾，細断後の段階で成分分析に供した．ま た，サイレージは屋外で 6 週間以上貯蔵した後に各草種,

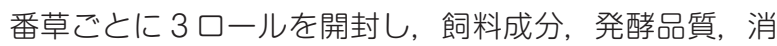
化率および栄養価の分析に供した。

\section{2. 測定項目および方法}

1）成分分析

サイレージ材料草およびサイレージを通風乾燥機で予備 乾燥 $\left(60^{\circ} \mathrm{C}, 48\right.$ 時間) 後に $1 \mathrm{~mm}$ メッシュの節を通過す るよう粉砕（SM2000；レッチェ，東京）し，DM，有機 物 (OM), CP, 粗脂肪 (EE), 耐熱性 $a$ アミラ一ゼ処理 中性デタージェント䋊維 (aNDFom), 酸性デタージェン 卜繊維（ADFom）および酸性デタージェントリグニン

表 3 オーチャードグラス・ペレニアルライグラス混播 草地早刈り, 短間隔刚り体系およびチモシ一主体草地年間 2 回刈り体系における材料草の収量（宮地ら 2020）

\begin{tabular}{lccccc}
\hline \hline \multirow{2}{*}{ (t/ha) } & \multicolumn{3}{c}{$\mathrm{OG} \cdot \mathrm{PR}$} & \multicolumn{2}{c}{$T Y$} \\
\cline { 2 - 6 } & 1 番草 & 2 番草 & 3 番草 & 1 番草 & 2 番草 \\
\hline DM & 4.7 & 2.9 & 1.7 & 8.5 & 3.0 \\
TDN & 3.1 & 1.8 & 1.1 & 5.2 & 1.7
\end{tabular}

OG : オーチャードグラス, PR :ペレ二アルライグラス, TY : チモシ一, DM : 乾物, TDN : 可消化養分総量

表 2 オーチャードグラス・ペレ二アルライグラス混播草地早刈り, 短間隔刈り体系およびチモシ一 主体草地年間 2 回刈り体系における材料草の刚り取り日および収穫曰（宮地ら 2020）

\begin{tabular}{|c|c|c|c|c|c|c|c|c|}
\hline & \multicolumn{5}{|c|}{ 刈り取り日 } & \multicolumn{3}{|c|}{ 収穫曰 } \\
\hline & 1 番草 & $\begin{array}{c}\text { 再生日数 } \\
(\text { (日) }\end{array}$ & 2 番草 & $\begin{array}{c}\text { 再生日数 } \\
(日)\end{array}$ & 3 番草 & 1 番草 & 2 番草 & 3 番草 \\
\hline$O G \cdot P R$ & $5 / 28$ & 42 & $7 / 9$ & 42 & $8 / 20$ & $5 / 28$ & $7 / 9$ & $8 / 20$ \\
\hline TY & $6 / 18$ & 63 & $8 / 20$ & - & - & $6 / 19$ & $8 / 20$ & - \\
\hline
\end{tabular}

OG : オーチャードグラス, PR : ペレニアルライグラス, TY : チモシー

$\mathrm{OG} \cdot \mathrm{PR}$

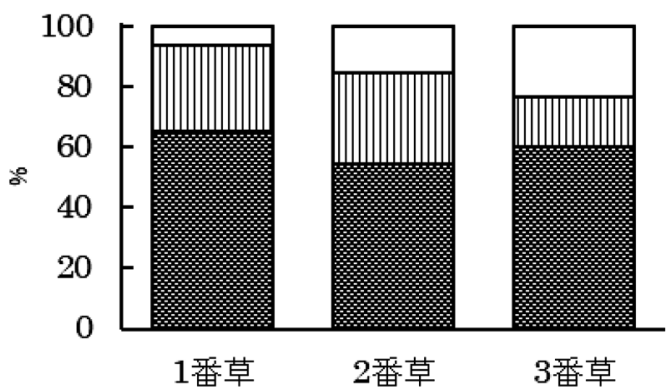

TY

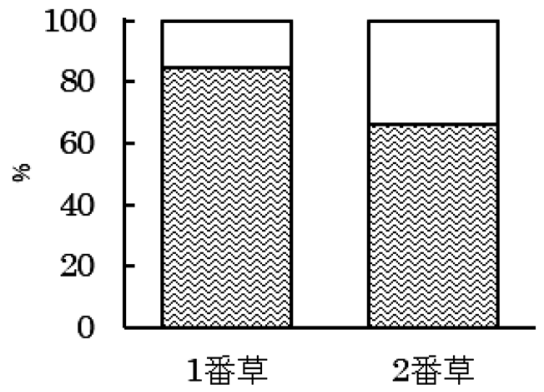

\section{圆 OG 四PR 图TY 口雑草·枯死部など}

図 1 オーチャードグラス・ペレ二アルライグラス混播草地早刈り, 短間隔刈り体系およびチモシー 主体草地年間 2 回刈り体系における材料草の草種構成（宮地５ 2020）

OG : オーチャードグラス, PR : ペレ二アルライグラス, TY : チモシー

草種構成は, 刈り取り後の材料草を草種ごとに選別し，各草種の乾物重あたりの割合として算出した 


\section{混播牧草サイレージの飼料特性}

（ADL）の分析に供した. 分析方法は自給飼料利用研究会 （2009）に準じた. また, サイレージ材料草はアンスロン 法（篠田ら 2016）によりWSC の分析を行った.

2) 発酵品質

サイレージの新鮮物 $40 \mathrm{~g}$ を蒸留水 $140 \mathrm{~mL}$ に浸漬して, 一晚冷蔵後に得た抽出液を分析試料とし, pHをガラス電 極 $\mathrm{pH}$ メーター（F-21; 堀場製作所(株), 京都) を用い て測定した．また，有機酸含量は高速液体クロマトグラ フィー (HPLC) (L-2000 シリーズ ; 日立製作所, 東京) を 用いてブロモチモールブルーによるポストラベル法（大桃 ら 1993) で分析した. エタノール含量も HPLC (L-2000 シリーズ；日立製作所）を用いて測定し，カラムはRSPac $\mathrm{KC}-811$, 力ラム温度は $60^{\circ} \mathrm{C}$, 移動相は $3 \mathrm{mM}$ 過塩素酸, 流速は $1 \mathrm{~mL} / \mathrm{h}$, 注入量は $20 \mu \mathrm{L}$, 検出器は示差屈折計と した. 揮発性塩基態窒素 (VBN) は水蒸気蒸留法（自給 飼料利用研究会 2009）により測定し、VBN の全窒素含 量に対する割合 (VBN/TN) を算出した. さらに, 乳酸 を除く有機酸含量とVBN/TN に基づき，Vスコアを算出 した (自給飼料利用研究会 2009).

3）消化率および栄養価

サイレージの消化率および栄養価は, ヒツジを用いた全 糞採取法によつて査定した（自給飼料利用研究会 2009）. 各草種, 番草ごとにコリデール種去勢成ヒツジ 4 頭 (平均 体重 $65.0 \pm 7.2 \mathrm{~kg}$ ) を割り当て, 単飼条件で各サイレー ジを1頭 1 日当たり乾物として体重の $1.8 \%$ の量を目安 として 1 日1回給与した. 飲水および舐塩は自由とした. 10日間の馴致期間に引き続き, 4日間にわたり残飼量およ び排筫量を測定するとともに，4日分をまとめて個体ごと の残飼および䔬試料を得た．この間に給与飼料の代表的な 試料も採取した. 給与飼料, 残飼および䔬の各試料につい て, 前述の方法で成分含量を分析し, 供試サイレージの各 成分消化率を算出するとともに, 可消化養分総量 (TDN)
含量を算出した，本報告における動物実験は，北海道農業 研究センタ一動物実験等実施要領に基づいて実施した。

\section{3. 統計解析}

サイレージの発酵品質, 成分, 消化率および栄養価につ いては一元配置分散分析を行い, サイレージの種類による 影響が有意であった項目については Tukey の多重比較を 行った. 統計処理には R version 3.4.3 (R Core Team 2017）を用いた.

\section{結果および考察}

\section{1. サイレージ材料草の WSC 含量およびサイレージの}

\section{発酵品質}

サイレージ材料草の成分を表 4 に示した. 本試験では, 材料草は収穫後 DM 含量 25〜30\% を目途に予乾を行つ たものの, 天候や草量によっては想定より予乾が進む場 合があった. 特に, 草量の少ない $O G \cdot P R 3$ 番草や TY2 番草においてDM 含量が高かった. WSC 含量はすべての 草種, 番草で $8.0 \% \mathrm{DM}$ 以上であり, OG.PR1 番草で 21.8\% DM と最も高い値であった。

サイレージの発酵品質に関するデータを表 5 に示した. $O G \cdot P R 2$ 番草でプロピオン酸が $0.06 \%$ DM, TY1 番草

表 4 オーチャードグラス・ペレニアルライグラス混播 草地早刈り, 短間隔刈り体系およびチモシ一主体草地年間 2 回刈り体系における材料草の成分

\begin{tabular}{lccccc}
\hline \hline \multirow{2}{*}{$(\%)^{1}$} & \multicolumn{3}{c}{ OG·PR } & \multicolumn{2}{c}{$T Y$} \\
\cline { 2 - 6 } & 1 番草 & 2 番草 & 3 番草 & 1 番草 & 2 番草 \\
\hline DM & 24.7 & 24.4 & 44.2 & 36.8 & 60.5 \\
WSC & 21.8 & 9.4 & 8.0 & 12.0 & 10.3
\end{tabular}

OG: オーチャードグラス, PR:ペレニアルライグラス, TY : チモシ一, DM : 乾物, WSC : 可溶性炭水化物 ${ }^{1}$ DM は原物中, WSC は DM 中含量を示す

表 5 オーチャードグラス・ペレ二アルライグラス混播草地早刚り, 短間隔刚り体系およびチモシ一主体 草地年間 2 回刚り体系によって生産されたサイレージの発酵品質

\begin{tabular}{|c|c|c|c|c|c|c|c|}
\hline & \multicolumn{3}{|c|}{$O G \cdot P R$} & \multicolumn{2}{|c|}{ TY } & \multirow{2}{*}{ SEM } & \multirow{2}{*}{$P$} \\
\hline & 1 番草 & 2 番草 & 3 番草 & 1 番草 & 2 番草 & & \\
\hline $\mathrm{pH}$ & $3.71^{\mathrm{b}}$ & $3.93^{\mathrm{a}}$ & $3.85^{\mathrm{a}}$ & $3.88^{\mathrm{a}}$ & $3.93^{\mathrm{a}}$ & 0.02 & $<0.01$ \\
\hline \multicolumn{7}{|l|}{ 有機酸含量（\%DM） } & 0.01 \\
\hline 酰酸 & $2.02^{\mathrm{ab}}$ & $3.20^{\mathrm{a}}$ & $1.30^{\mathrm{b}}$ & $0.96^{b}$ & $0.31^{\mathrm{b}}$ & 0.31 & $<0.01$ \\
\hline プロピオン酸 & ND & 0.06 & ND & ND & ND & & \\
\hline 酪酸 & ND & ND & ND & 0.04 & ND & & \\
\hline エタノール (\%DM) & $3.67^{a}$ & $0.80^{b}$ & $0.44^{b}$ & $1.55^{\mathrm{b}}$ & $0.36^{b}$ & 0.30 & $<0.01$ \\
\hline VBN/TN (\%) & $5.10^{b}$ & $8.16^{\mathrm{a}}$ & $4.34^{b}$ & $7.14^{\mathrm{a}}$ & $4.18^{b}$ & 0.21 & $<0.01$ \\
\hline レスコア & 98 & 89 & 99 & 94 & 100 & & \\
\hline
\end{tabular}

OG : オーチャードグラス, PR : ペレニアルライグラス, TY : チモシー, DM : 乾物, VBN/TN : 全窒 素含量に対する揮発性塩基態窒素の割合, ND : 不検出, SEM : 平均値の標準誤差

a, b 異符号間に有意差あり $(P<0.05)$ 
で酪酸が 0.04\% DM 検出されたが，いずれのサイレージ とも $\mathrm{pH}$ は 3.71〜3.93, VBN/TN は 10\% 以下で, Vス コアも良質サイレージの目安である 80 以上のサイレージ であった. すべてのサイレージの中で, OG.PR1 番草は $\mathrm{pH}$ が 3.71 と有意に低< $(P<0.05)$, エタノール含量 は 3.67\% DM と有意に高かった $(P<0.05)$ ．また, 有 意差は認められなかったものの, 乳酸含量も $8.97 \% \mathrm{DM}$ と最も高い値であった.

良好な発酵品質のサイレージを得るためにはサイレージ の材料草に一定量以上の WSC が含有される必要がある. 増子の報告（2017）では, WSC の必要量を無予乾草で 9.1\% DM, 予乾草で 7.6\% DM 以上としている. 本試験 で用いたサイレージ材料草の WSC 含量は, 予乾が進み DM 含量の高かった OG.PR3 番草で $8.0 \%$ DM, その他 の草種, 番草では $9.4 \%$ DM 以上であった. したがって, 本試験ではサイレージ材料草にWSC が十分に含まれてい たことから, 調製されたサイレージの発酵品質がいずれも 良好であったと考えられる. 中でも, WSC 含量が最も高
かった OG.PR1 番草のサイレージは, $\mathrm{pH}$ が最も低 $<$, 乳酸及びエタノール含量が最も高かった. これは, 他のイ ネ科牧草に比べ WSC 含量が高いPR の特性を反映したも のと考えられた（増子ら 1994a, b ; 岡元亡古館 2007).

\section{2. サイレージの成分, 消化率および栄養価}

サイレージの飼料成分を表 6 に示した. サイレージ材 料草の DM 含量と同様に, TY2 番草において DM 含量が 最も高かった $(P<0.05)$. OM 含量は OG.PRの方が TY に比べ有意に低かった $(P<0.05)$. EE 含量には草種 および番草による差が認められなかった，CP 含量は番草 ごとに比較すると, 1 番草と 2 番草ともに $O G \cdot P R$ の方 がTYに比べ有意に高かった $(P<0.05)$ ，一方で，繊維 成分の含量は aNDFom, ADFom, ADL すべてで OG. $P R$ の方がTYに比べ有意に低かった $(P<0.05)$.

サイレージの消化率およびTDN 含量を表 7 に示した. DM および aNDFom 消化率と TDN 含量は, OG・PR1 番草で最も高 $<$, 次いで $O G \cdot P R 2$ 番草が高かった $(P<$ 0.05). CP 消化率は番草ごとに比較すると, 1 番草と 2

表 6 オーチャードグラス・ペレニアルライグラス混播草地早刈り, 短間隔刚り体系および チモシ一主体草地年間 2 回刈り体系によって生産されたサイレージの成分

\begin{tabular}{|c|c|c|c|c|c|c|c|}
\hline \multirow{2}{*}{$(\%)^{1}$} & \multicolumn{3}{|c|}{$O G \cdot P R$} & \multicolumn{2}{|c|}{ TY } & \multirow{2}{*}{ SEM } & \multirow{2}{*}{$P$} \\
\hline & 1 & 2 & 3 & 1 & 2 & & \\
\hline $\mathrm{DM}$ & $22.1^{\circ}$ & $22.4^{\circ}$ & $41.1^{\mathrm{b}}$ & $33.1^{\mathrm{b}}$ & $56.8^{a}$ & 1.28 & $<0.01$ \\
\hline OM & $91.3^{b}$ & $89.2^{c}$ & $90.0^{\circ}$ & $93.0^{\mathrm{a}}$ & $92.2^{\mathrm{a}}$ & 0.14 & $<0.01$ \\
\hline $\mathrm{CP}$ & $12.0^{\mathrm{b}}$ & $16.6^{a}$ & $16.7^{\mathrm{a}}$ & $8.0^{\circ}$ & $10.1^{\mathrm{b}}$ & 0.33 & $<0.01$ \\
\hline EE & 5.6 & 6.4 & 4.3 & 3.7 & 3.6 & 0.62 & 0.13 \\
\hline aNDFom & $53.7^{\circ}$ & $52.3^{\mathrm{cd}}$ & $50.3^{d}$ & $67.9^{a}$ & $60.6^{b}$ & 0.46 & $<0.01$ \\
\hline ADFom & $32.4^{\circ}$ & $34.1^{c}$ & $32.8^{c}$ & $42.9^{a}$ & $37.4^{b}$ & 0.34 & $<0.01$ \\
\hline ADL & $2.2^{e}$ & $3.3^{d}$ & $4.6^{c}$ & $5.2^{b}$ & $5.9^{\mathrm{a}}$ & 0.07 & $<0.01$ \\
\hline \multicolumn{8}{|c|}{ 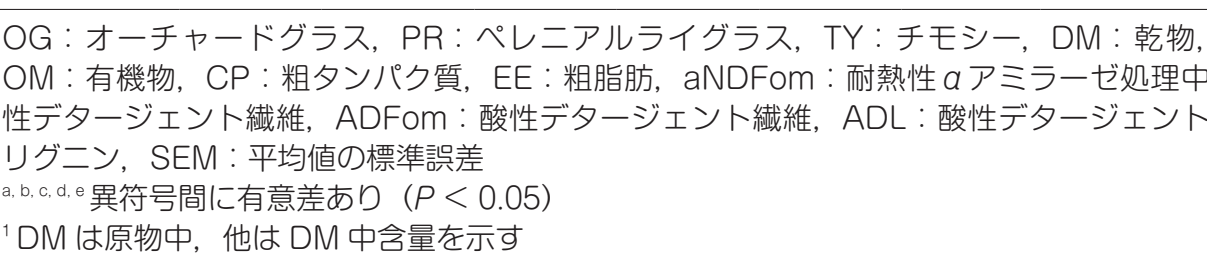 } \\
\hline
\end{tabular}

表 7 オーチャードグラス・ペレニアルライグラス混播草地早刈り, 短間隔刚り体系および チモシ一主体草地年間 2 回刈り体系によって生産されたサイレージの消化率および栄養価

\begin{tabular}{llllllll}
\hline \hline \multirow{2}{*}{$(\%)$} & \multicolumn{5}{c}{ OG.PR } & \multicolumn{5}{c}{ TY } & \multirow{2}{*}{ SEM } & $P$ \\
\cline { 2 - 5 } & 1 番草 & 2 番草 & 3 番草 & 1 番草 & 2 番草 & & \\
\hline DM & $70.1^{\mathrm{a}}$ & $63.9^{\mathrm{b}}$ & $59.3^{\mathrm{c}}$ & $56.0^{\mathrm{c}}$ & $54.9^{\mathrm{c}}$ & 0.87 & $<0.01$ \\
$\mathrm{CP}$ & $55.7^{\mathrm{bc}}$ & $63.7^{\mathrm{a}}$ & $58.2^{\mathrm{b}}$ & $46.2^{\mathrm{d}}$ & $51.4^{\mathrm{c}}$ & 0.93 & $<0.01$ \\
NDF & $73.4^{\mathrm{a}}$ & $69.5^{\mathrm{a}}$ & $61.2^{\mathrm{b}}$ & $58.1^{\mathrm{b}}$ & $56.2^{\mathrm{b}}$ & 1.10 & $<0.01$ \\
TDN & $68.3^{\mathrm{a}}$ & $62.9^{\mathrm{b}}$ & $58.0^{\mathrm{c}}$ & $54.8^{\mathrm{c}}$ & $54.4^{\mathrm{c}}$ & 0.74 & $<0.01$ \\
\hline
\end{tabular}

$\mathrm{OG}:$ オーチャードグラス, PR:ペレニアルライグラス, TY : チモシー, DM : 乾物, CP : 粗タンパク質, aNDFom : 耐熱性 $a$ アミラーゼ処理中性デタージェント繊維, TDN : 可消化養分総量, SEM : 平均値の標準誤差 a b b, c, d 異符号間に有意差あり $(P<0.05)$ 


\section{混播牧草サイレージの飼料特性}

番草ともに $O G \cdot P R$ 方がTYに比べ有意に高かった $(P$ $<0.05)$.

本試験で確認された, CP およびTDN 今量が高<, 繊 維含量が低いという OG.PR サイレージの飼料特性は, 早刈りと引き続く短間隔刈りにおいて期待される一般的な 利点によるものと考えられた (Kuoppala 5 2008). ま た, OG・PR 材料草には高栄養な草種である PR（増子 ら 1994a, b) が 2 3 割程度含まれていた (図 1) ことも, OG・PR サイレージの高栄養化につながったと推察され る. さらに, 各 1 番材料草における雑草・枯死部などの割 合は, 出穂期刚りしたTYでは $15.4 \%$ DM であったのに 対し, 早刚りした OG・PR では $6.2 \% \mathrm{DM}$ と低かった (図 1).このことも, 両サイレージの栄養価の違いに影響を 及ぼしていたと考えられる。

以上のように, 慣行の TY1 番草出穂期刚りによる年間 2 回刚り体系に比べ, OG.PRの早刈り, 短間隔刈り体 系では, 特に 1 番草でサイレージ材料草の WSC 含量が 高く, 生産されるサイレージの発酵品質が良好であった. また, OG・PRサイレージは CP およびTDN 含量が高 く纎維含量が低しことが明らかになった．本試験で示した $O G \cdot P R$ の収穫体系では刈り取り回数や作業時間が増加 する一方で, 飼料費の低減が期待される（宮地5 2020）. 以上より, 本体系で生産されるサイレージには発酵品質や 栄養価の面でメリットが大きいものの, 労力や人手の面で はデメリットとなる場合も考えられるため, 今後どのよう な営農場面で適応できるかを検討する必要がある。

\section{謝辞}

本試験を実施するに当たり, 農研機構北海道農業研究也 ンター業務第 1 科の職員諸氏には多大なる支援を, 分析 に際しては同センタ一酪農研究領域契約職員の東谷和葉 氏, 山形麻利子氏の助力をいただいた. また, 農研機構北 海道農業研究センタ一酪農研究領域大下友子領域長に本稿 を校閲いただいた，ここに記して，感謝の意を表する。 な お, 本研究は農林水産省委託プロジェクト研究「栄養収量 の高い国産飼料の低コスト生産・利用技術の開発」の補助 を受けて行った.

\section{文献}

出口健三郎. 2016. 北海道の採草地における草種構成恶化の現状 とその要因. 日本草地学会誌 62, 153-157.

藤井弘毅. 2010. チモシ一. 牧草 ·飼料作物の品種解説（日本草 地畜産種子協会編)。pp. 40-49. 日本草地畜産種子協会, 東 京.

自給飼料利用研究会 (編). 2009. 三訂版粗䬰料の品質評価ガイ ドブック． pp. 1-195. 日本草地畜産種子協会, 東京。

上川農試天北支場. 2016. オーチャードグラス, ペレ二アルライ グラス混播導入によるリードカナリーグラス草地の改善効
果. 平成 27 年度北海道農業試験会議成績概要書.

木曾誠二, 能代昌雄. 1994. チモシー (Phleum pretense L.) 採草地の早刈り管理法. 1. 早刚りが単播草地の乾物収量, 可消化養分総量および雑草侵入に及ぼす影響. 日本草地学会 誌 39, 429-436.

木曾誠二, 能代昌雄. 1997. チモシー (Phleum pretense L.) 採草地の早刚り管理法. 2. 早刚りがチモシー・シロクロー バ (Trifolium repens L.) 混播草地の草種構成, 乾物収量 および可消化養分総量に及ぼす影響. 日本草地学会誌 43 , 258-265

北村 亨. 2016. 地下茎型イネ科草種がサイレージ発酵品質や栄 養価に及ぼす影響. 日本草地学会誌 62, 158-162.

小林良次. 2014a. チモシー. 最新畜産八ンドブック（扇元敬司. 韮澤圭二朗·桑原正貴·寺田文典・中井 裕·杉浦勝明編集). p. 189. 講談社サイエンティフィク, 東京.

小林良次. 2014b. オーチャードグラス. 最新畜産八ンドブック (扇元敬司・韮澤圭二朗・桑原正貴 · 寺田文典・中井 裕・杉 浦勝明編集). p. 189. 講談社サイエンティフィク, 東京.

Kuoppala K, Rinne M, Nousiainen J, Huhtanen P. 2008. The effect of cutting time of grass silage in primary growth and regrowth and the interactions between silage quality and concentrate level on milk production of dairy cows. Livestock Science 116, 171-182.

McDonald P. Henderson AR, Heron SJE. 1991. The biochemistry of silage, 2nd edn., pp. 1-340. Chalcombe Publications, Bucks, Great Britain.

増子孝義. 2017. 酪農家およびTMR センターにおける牧草サイ レージの発酵品質向上に向けた診断の提案. 紀要論文, 東京 農業大学.

増子孝義, 兒玉厳雄, 植松 斉, 久保井栄, 前田良之, 山中良忠. 1994b. 北海道で栽培した寒地型イネ科牧草における単糖・ 二糖類今量の生育ステージ別, 刈取り回次別変化. 日本草地 学会誌 40, 230-233.

増子孝義, 小野淳史, 古川信明, 大谷 忠. 1994a. 北海道で栽 培した寒地型イネ科牧草における粗蛋白質, ADF および可溶 性糖類 (WSC) 含量の生育ステージ別, 刈取り回次別変化. 日本草地学会誌 40, 227-229.

宮地 慎, 矢島 昂, 須藤賢司, 青木康浩. 2020。年 4 回㺫り 利用のオーチャードグラス (Dactylis glomerata L.) ・ペレ ニアルライグラス (Lolium perenne L.) 混播採草地と年 2 回刚り利用のチモシー（Phleum pratense L.）採草地の草 種構成および栄養収量. 日本草地学会誌 65, 250-256.

大桃定洋, 田中 治, 北本宏子. 1993. 高速液体ク口マトグラ フィーによるサイレージ中の有機酸の定量. 草地試験場研究 報告 48, 51-56.

岡元英樹, 古館明洋. 2007. 天北地方における主要イネ科 3 草 種の採草利用時の生育. 飼料特性. 道立農試集報 $75,41-$ 46.

R Core Team. 2017. R : A language and environment for statistical computing. R Foundation for Statistical Computing, Vienna, Austria. Available from URL https://www.R-project.org/.

篠田英史, 出口健三郎, 飯田憲司, 足利和紀, 増子孝義. 2016. 牧草中の可溶性炭水化物含量測定におけるアンスロン法の改 変. 日本草地学会誌 62, 1-7.

谷津英樹. 2017. 寒地型牧草の特性と栽培利用時における留意点 (北海道)。牧草と園芸 65 (2), 1-4. 


\title{
Forage characteristics of grass silage made from orchardgrass and perennial ryegrass mixed meadow, harvested early and at short intervals in Hokkaido
}

\author{
Akira YAJIMA', Kenji SUDO'1, Shingo TADA', Makoto MIYAJI' and Yasuhiro AOKI'1 \\ ${ }^{1}$ NARO Hokkaido Agricultural Research Center, Sapporo 062-8555, Japan \\ Corresponding : Akira YAJIMA (fax : +81 (0) 11-859-2178, e-mail : yajimaa156@affrc.go.jp)
}

\begin{abstract}
We investigated the water soluble carbohydrate (WSC) concentrations of forages and the chemical composition, the fermentation quality, and the nutritive value of silage made from orchardgrassperennial ryegrass (OG-PR) mixed meadow, harvested early and three times a year at short intervals, compared to those made from timothy (TY) meadow, harvested twice a year in Hokkaido. The WSC concentration of OG-PR first cut forage was higher than those of other forages. OG-PR first cut silage showed good fermentation quality with high lactate acid content. OG-PR silage contained more crude protein and total digestive nutrients estimated by total fecal collection method using wether, and less fiber than TY silage. These results indicated that grass silage made from OG-PR mixed meadow, harvested early and at short intervals, has advantages in improving the fermentation quality and the nutritive value.
\end{abstract}

Nihon Chikusan Gakkaiho 91 (3), 275-280, 2020

Key words : fermentation quality, grass silage, nutritional value, orchardgrass, perennial ryegrass. 